\title{
Elevated Activity of Dolichyl Phosphate Mannose Synthase Enhances Biocontrol Abilities of Trichoderma atroviride
}

\author{
Patrycja Zembek, ${ }^{1,2}$ Urszula Perlińska-Lenart, ${ }^{1}$ Kurt Brunner, ${ }^{2}$ Barbara Reithner, ${ }^{2}$ \\ Grażyna Palamarczyk, ${ }^{1}$ Robert L. Mach, ${ }^{2}$ and Joanna S. Kruszewska ${ }^{1}$ \\ ${ }^{1}$ Institute of Biochemistry and Biophysics, Polish Academy of Sciences, Pawińskiego 5a, 02-106 Warsaw, Poland; ${ }^{2}$ Institute \\ of Chemical Engineering, Gene Technology Group, Getreidemarkt 9/166/5/2, Vienna University of Technology, A-1060 Vienna, \\ Austria
}

Submitted 3 February 2011. Accepted 2 July 2011.

\begin{abstract}
Antagonism of Trichoderma spp. against phytopathogenic fungi is widely exploited for biocontrol of plant diseases. A crucial role in the biocontrol mechanism is attributed to cell-wall-degrading enzymes secreted by Trichoderma spp. Therefore, more efficient production and secretion of the enzymes should elevate the biocontrol abilities of Trichoderma spp. Because the majority of secretory hydrolases are glycoproteins, it has been postulated that the posttranslational modification of these proteins could constitute a bottleneck in their production and secretion. Our previous study showed that improvement of $\mathrm{O}$-glycosylation elevated protein secretion by Trichoderma reesei. In this study, we enhanced the biocontrol abilities of $T$. atroviride $P 1$ against plant pathogens by overexpressing the Saccharomyces cerevisiae DPM1 gene coding for dolichyl phosphate mannose (DPM) synthase, a key enzyme in the O-glycosylation pathway. The transformants we obtained showed doubled DPM synthase activity and, at the same time, significantly elevated cellulolytic activity. They also revealed an improved antifungal activity against the plant pathogen Pythium ultimum.
\end{abstract}

Trichoderma sp. strains are widely used as biological control agents due to their strong antagonistic abilities against phytopathogenic fungi and simultaneous action as promoters of plant growth and defense mechanisms (Benitez et al. 2004; Harman 2006; Hjeljord and Tronsmo 1998; Woo et al. 2006). The biocontrol effect often results from a direct interaction between the pathogen and Trichoderma spp., when the lytic enzymes secreted by the latter degraded the cell wall of the pathogen (Benitez et al. 2004; Chet et al. 1998; Viterbo et al. 2002).

Based on this finding, many studies have been undertaken to enhance the lytic activity of Trichoderma strains by overexpression of genes coding for lytic enzymes such as glucanases, chitinases, or proteases (Baek et al. 1999; Carsolio et al. 1999; Djonovic et al. 2006; Flores et al. 1997; Steyaert 2004). An improved biocontrol activity against Rhizoctonia solani was observed for Trichoderma harzianum carrying from 3 to 10 copies of the protease-encoding gene prbl (Flores et al. 1997). Unexpectedly, the highest activity of the protease found in a strain bearing five copies of the prbl gene did not exactly correlate with the highest prbl mRNA level found in strains with

Corresponding author: J. S. Kruszewska; Telephone: (+ 48 22) 59212 09; Fax: (+48 22) 65846 36; E-mail: jsk@ibb.waw.pl seven or four copies of the gene. Even more surprisingly, the best biocontrol activity was exhibited by a strain with six copies of the gene and an average protease activity (Flores et al. 1997).

On the other hand, overexpression of a chitinase gene (cht42) in T. virens Gv29-8 did not significantly improve its biocontrol activity (Baek et al. 1999). Furthermore, $\beta$-1,6-glucanase (bgn3) overexpressed in T. virens, even though effective in growth inhibition of Pythium ultimum, gave only slightly better protection of seedlings compared with that of a control wild type strain (Djonovic et al. 2006).

Numerous authors have observed a natural increase in the expression of lytic enzymes upon a mycoparasitic contact (Kulling et al. 2000; Montero et al. 2007; Suarez et al. 2005; Yan and Qian 2009; Zeilinger et al. 1999). Screening for genes induced before and during mycoparasitic contact allowed the identification of genes coding for proteins from three functional groups, including those involved in protein synthesis and in the hydrolysis of macromolecules (Scherm et al. 2009). The authors of those studies noticed that, in general, the activation concerned enzymes necessary for degradation of the cell wall of the pathogen and metabolism of its constituents and also, which adds credence to the present study, enzymes engaged in protein modifications.

Because overexpression of a single gene coding for a hydrolytic enzyme only slightly improved the biocontrol activity, other approaches have been tried. It was noticed that many if not all extracellular proteins secreted by Trichoderma spp. were glycosylated, and O-glycosylation was postulated to be closely connected with secretion in Trichoderma spp. (Kruszewska et al. 1999; Kubicek et al. 1987; Perlińska-Lenart et al. 2006). Moreover, the activity of a key enzyme in the Oglycosylation process, dolichyl phosphate mannose (DPM) synthase (EC 2.4.1.83), was observed to be upregulated in parallel with increased protein secretion (Kruszewska et al. 1990, 1999; Perlińska-Lenart et al. 2006).

Our earlier data indicated that overexpression of the Saccharomyces cerevisiae DPM1 gene in T. reesei increased the level of protein glycosylation and secretion: seven times more protein was secreted to the growth medium than in nontransformed cultures (Kruszewska et al. 1999). Additionally, overexpression of the mpglgene encoding guanylyltransferase in this strain (Zakrzewska et al. 2003) increased the level of GDP-mannose, a substrate for glycosylations, caused overglycosylation of the secreted enzymes. The result was a $40 \%$ overall increase in the total cellulolytic activity in the cultiva- 
tion medium (J. S. Kruszewska, G. Palamarczyk, and A. Zakrzewska, unpublished data).

In this study, we intended to improve the biocontrol abilities of $T$. atroviride $\mathrm{P} 1$ strain against fungal plant pathogens by overexpression of the $S$. cerevisiae DPMI gene coding for DPM synthase.

\section{RESULTS}

Overexpression of the $S$. cerevisiae DPM1 gene.

The biocontrol strain P1 of T. atroviride was transformed with the yeast DPM1 gene under the constitutive promoter of the gpdA gene (encoding glyceraldehyde-3-phosphate dehydrogenase) from Aspergillus nidulans. Transformants were selected on the basis of their resistance to hygromycin B. Genomic DNA was extracted from the obtained transgenic strains and screened by PCR and then Southern blotting for the presence of the yeast DPM1 gene integrated into the genome (Fig. 1). Southern blot analysis revealed three stable transformants giving two DNA bands hybridizing with a radioactive probe synthesized on the yeast DPMI DNA as a template. The pAN521N vector with the DPM1 open reading frame used for transformation has one EcoRI restriction site and, after transformation with the circular vector, the vector was linearized inside the cell and randomly integrated into unpredictable places; therefore, it was impossible to predict the size of DNA fragments hybridizing with the radioactive probe.

The transformants carrying the yeast gene were then analyzed by Northern hybridization for the amount of the corresponding transcript. A dot blot analysis with different dilutions of total RNA gave a strong signal proportional to the concentration of RNA (Fig. 2).

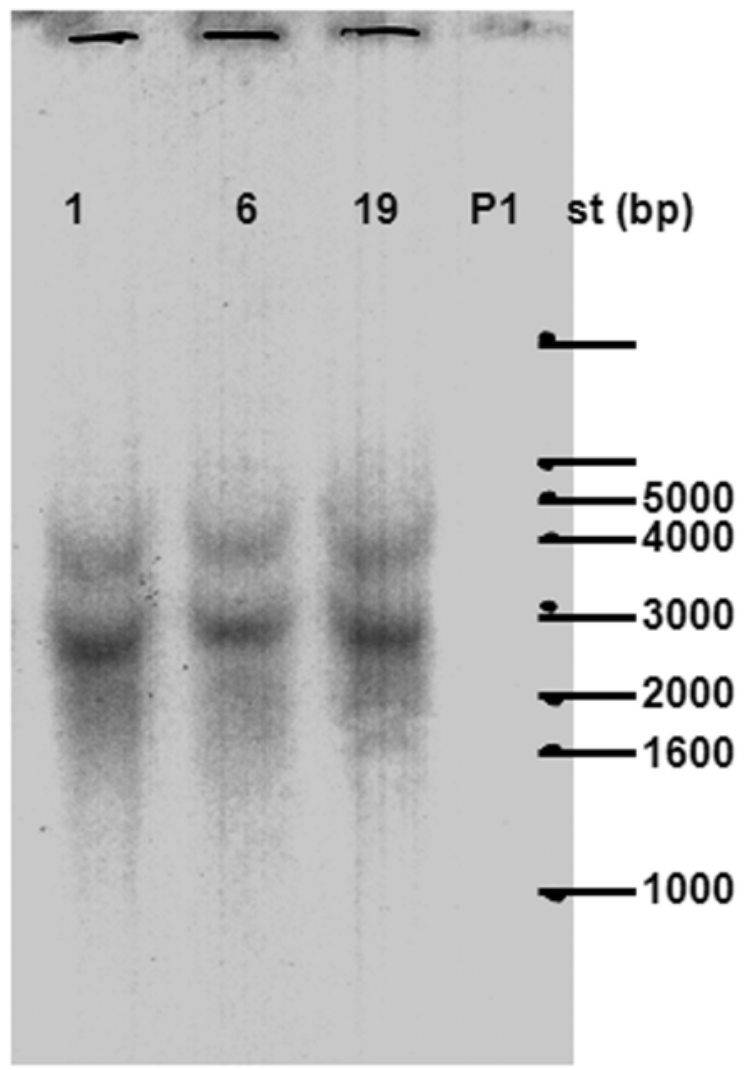

Fig. 1. Integration of $D P M 1$ gene in Trichoderma genomic DNA. Analysis of EcoRI-digested DNA of control nontransformed strain (P1) and DPMI transformants PZ1/06, PZ6/06, and PZ19/06 was hybridized with DNA probe synthesized on the template of Saccharomyces cerevisiae DPM1 gene coding sequence; $\mathrm{st}=$ molecular mass standard.
Characterization of the T. atroviride DPM1 transformants.

Because the yeast DPM1 gene used to transform T. atroviride $\mathrm{P} 1$ coded for DPM synthase, the key enzyme in O-glycosylation, we examined the activity of this enzyme in membranes obtained from the transformants and compared it with that from the control nontransformed strain.

The most pronounced increase, to $199 \%$ of the control DPM synthase activity, was noticed for the PZ1/06 strain. Two other strains, PZ6/06 and PZ19/06, showed slightly lower increase, to 161 and $164 \%$ of the control, respectively (Fig. 3).

Our study was based on the assumption that the increased activity of DPM synthase encoded by the DPM1 gene would stimulate protein secretion by the transformants. The increased amount of secreted hydrolytic enzymes should, in turn, improve the biocontrol properties of the obtained strains. For simple screening of the hydrolytic properties of the transformants, we

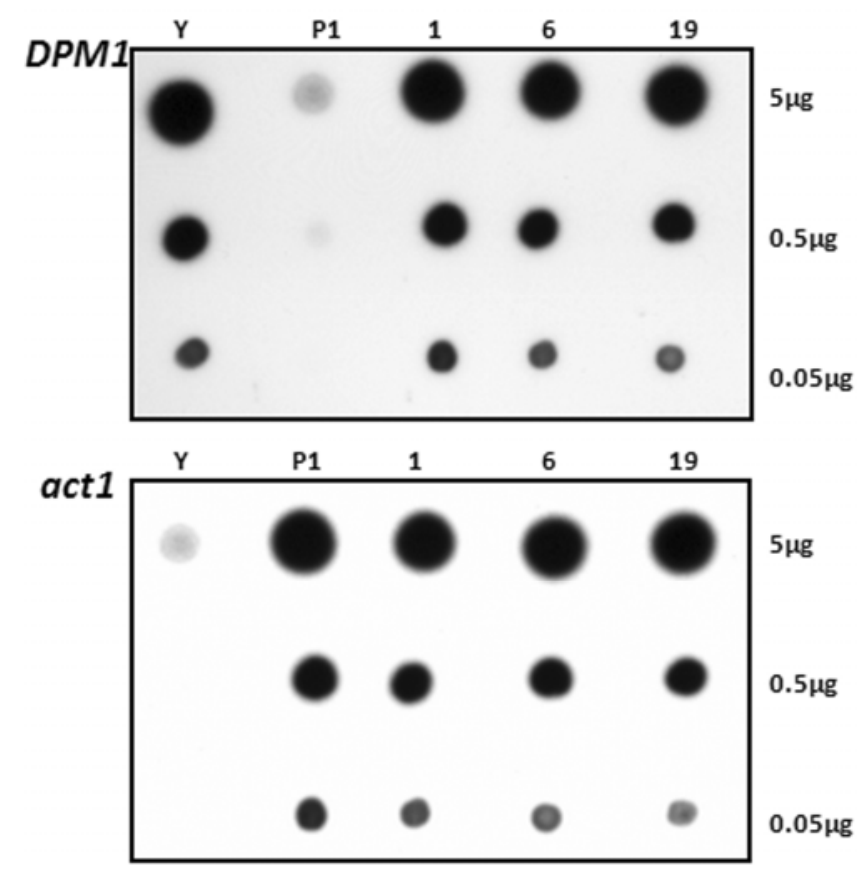

Fig. 2. DPM1 transcript levels in Trichoderma DPM1-transformants. Total RNA (from 5 to $0.05 \mu \mathrm{g}$ ) isolated from control strain P1 and DPM1-transformed strains (lane 1, PZ1/06; lane 6, PZ6/06; lane 19, PZ19/06) was dot blotted and hybridized with DNA probe synthesized on the template of Saccharomyces cerevisiae DPMIgene coding sequence and actl probe for control. Y-RNA from S. cerevisiae used as a positive control.

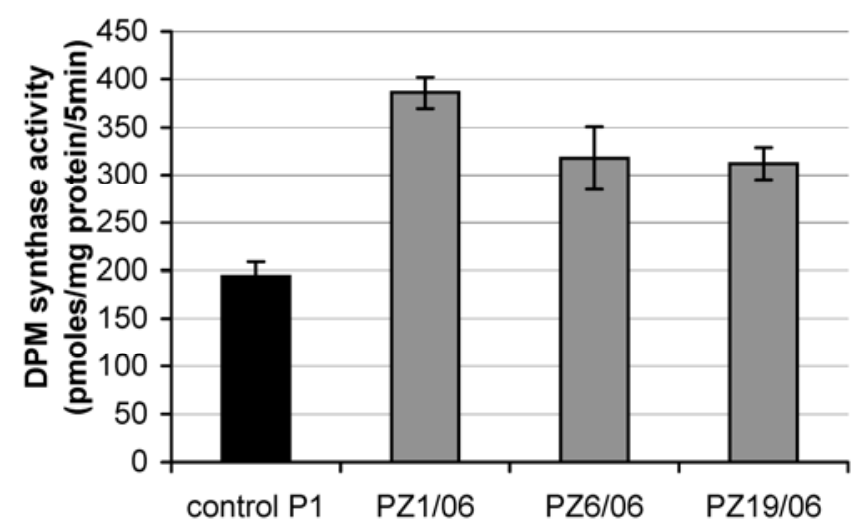

Fig. 3. Dolichyl phosphate mannose (DPM) synthase activity in membrane fractions from DPM1-transformed Trichoderma spp. Transformant strains PZ1/06, PZ6/06, and PZ19/06 and control strain P1 were processed and analyzed for DPM synthase activity. Data are presented as mean \pm standard deviation from six separate cultures. 
examined their growth on plates with MM supplemented with different polycarbohydrates such as xylan, cellulose, or carboxymethylcellulose as carbon sources. The area of growth was measured for 3 days and compared with that of the control strain (Fig. 4). All the transformants grew faster than the control strain, suggesting that their higher hydrolytic activity enabled more efficient utilization of the complex carbon sources. Differences in growth measured after 3 days of cultivation were statistically significant for all the carbon sources.

The cellulolytic activity of enzymes secreted to the liquid medium was measured for the transformants and the control strain and calculated per gram of dry mass of mycelia (Fig. 5). The cellulolytic activity was higher by 106,136 , and $64 \%$ in the culture medium from PZ1/06, PZ6/06, and PZ19/06, respectively, than for the control. Because the increased activity could be due to increased secretion of enzymatic proteins to the medium, we measured the amount of secreted proteins every $24 \mathrm{~h}$ for $264 \mathrm{~h}$ of cultivation in MM supplemented with lactose. Indeed, all three transformants secreted more protein than did the control strain. This increase of secretion was, however, substantially less pronounced that the observed augmentation of total cellulolytic activity, because it amounted to between 36 and 79\% (Fig. 5A). Moreover, there was little correlation between the amount of protein secreted and the cellulolytic activity (Fig. 5A and B). The growth kinetics of the strains in liquid MM with lactose was almost the same for the transformants and the control strain (Fig. 5C).

We also measured activity of $\mathrm{N}$-acetyl- $\beta$-D-glucosaminidase, an enzyme essential for chitinase induction in Trichoderma spp. (Brunner et al. 2003). This enzyme activity was higher by 85,75 , and $41 \%$ in the culture medium from PZ1/06, PZ6/06, and PZ19/06, respectively, than for the control (Fig. 6).

The elevated cellulolytic activity of the secreted proteins could have resulted not only from their higher concentration but also from differences in glycosylation. To address this possibility, total amount of carbohydrates bound to the secreted proteins was measured; however, no significant differences were found between the transformants and control (data not shown).

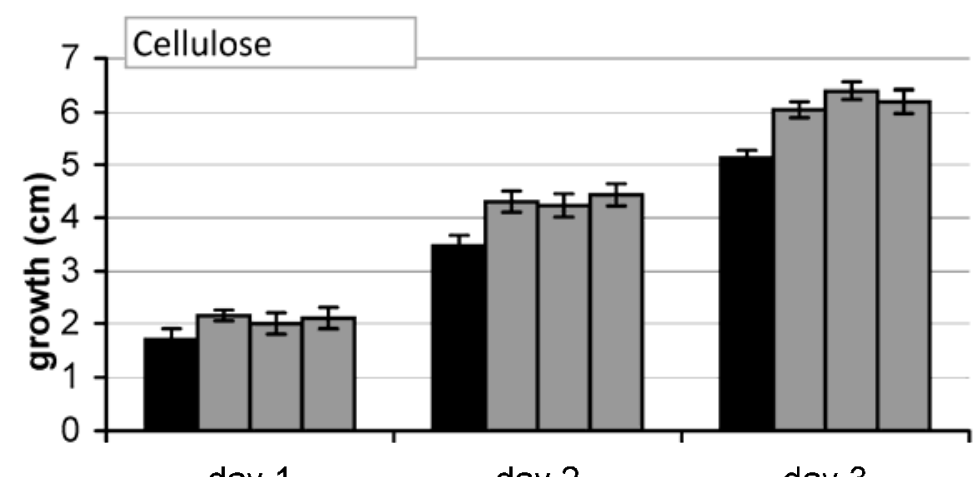

day 1

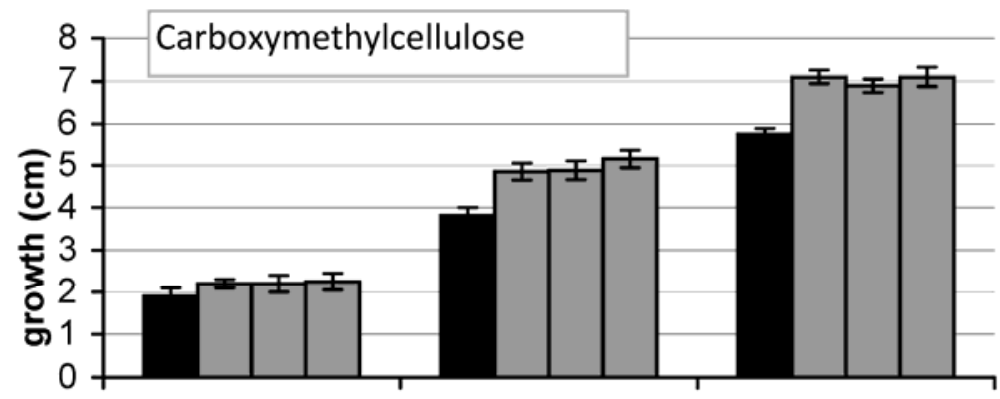

day 1

day 2

day 3

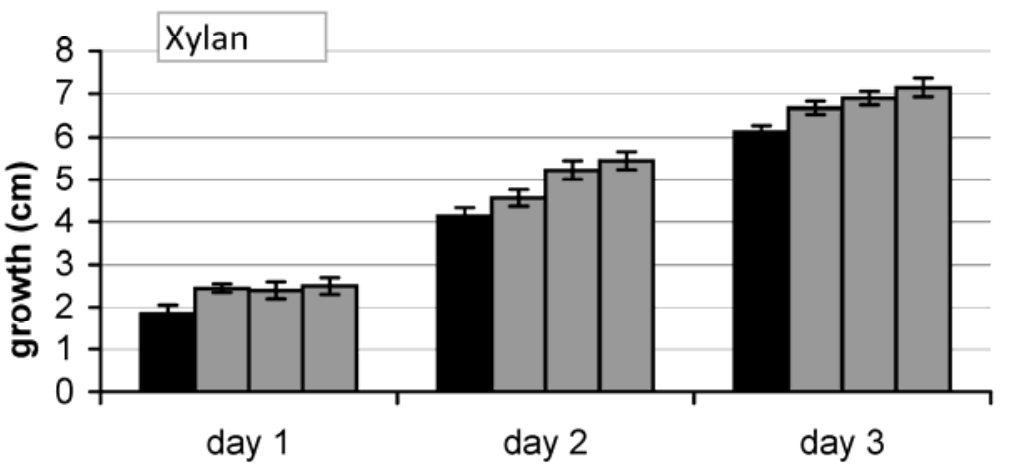

- control P1

口PZ1/06

口PZ6/06

口PZ19/06 control P1

口PZ1/06

$\square P Z 6 / 06$

口PZ19/06 control P1

口PZ1/06

$\square P Z 6 / 06$

$\square \mathrm{PZ} 19 / 06$

Fig. 4. Growth of DPM1-transformed Trichoderma atroviride strains on different carbon sources. PZ1/06, PZ6/06, and PZ19/06 transformants and the parental strain P1 were inoculated on minimal medium plates supplemented with complex carbohydrates as indicated, and their growth was followed by daily measurements of colony diameter. Data are presented as mean \pm standard deviation from six independent experiments. 


\section{Biocontrol properties.}

The Trichoderma strains transformed with the yeast DPMI gene secreted somewhat more proteins with a markedly higher cellulolytic activity. The more efficient utilization of cellulose by the transformants suggested that they could have improved antifungal properties. To verify this, we made a confrontation assay between the new Trichoderma strains and the pathogenic oomycete P. ultimum (Fig. 7). The cell wall of this plant pathogen consists mainly of $\beta-(1,3)$ glucan and some $\beta-(1,6)$ glucan and $\beta-(1,4)$ glucan (cellulose). Chitin, a major constituent of the cell wall in most fungi, has been detected in a small amount in only a few Oomycetes spp. (Latijnhouwers et al. 2003). Trichoderma and Pythium spp. were cultivated on a single plate from separate inocula and we observed that Pythium spp. were overgrown more rapidly by all the transformants than by the control P1 strain (Fig. 7). Next, three different areas on the plates were analyzed under the microscope to show whether Pythium mycelia were only overgrown by Trichoderma spp. or lysed (Fig. 8). Microscopic analysis revealed that prolonged contact of Pythium spp. with Trichoderma spp. resulted in lysis of its mycelia observed on square number 1 (Fig. 8). Lysis of Pythium hyphae was not observed on square number 2 , where duration of the contact with Trichoderma spp. was too short. Although a part of
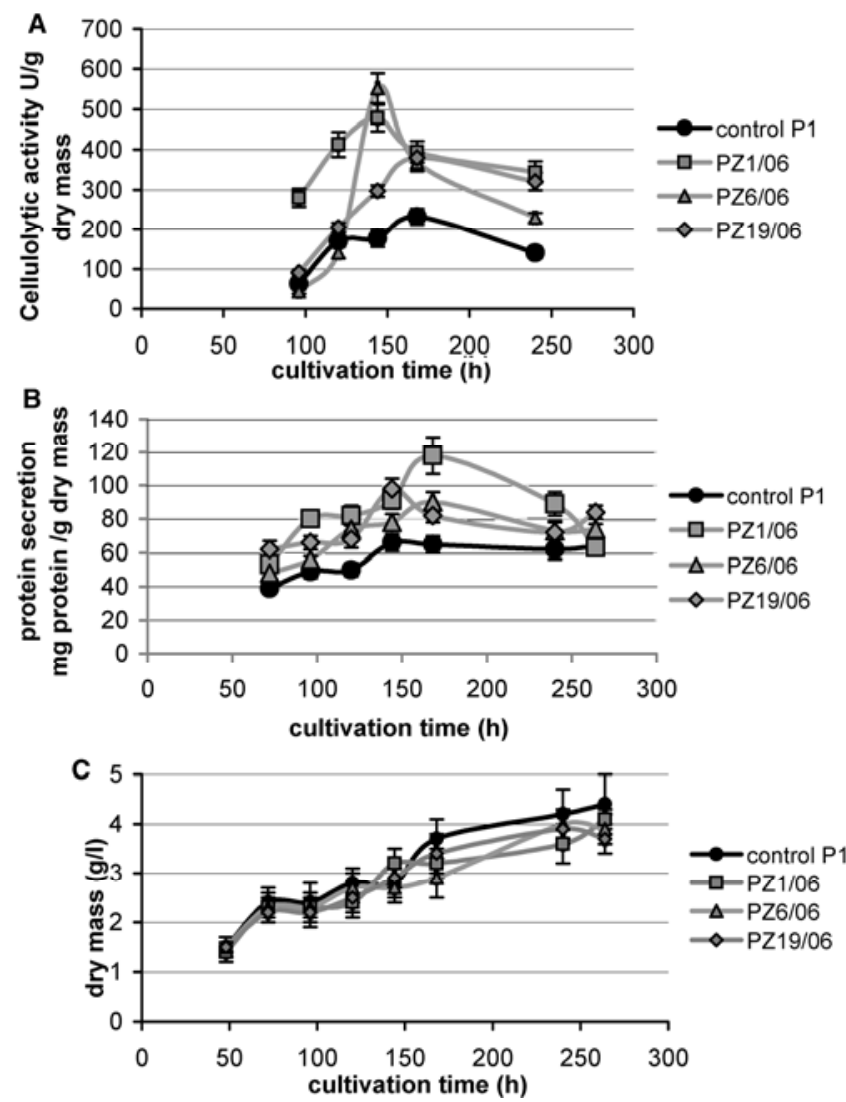

Fig. 5. Cellulolytic activity in cultivation medium from DPM1-transformed Trichoderma atroviride strains. A, Concentration of reducing sugars cleaved out from substrate (carboxymethylcellulose) was measured in cultivation medium from PZ1/06, PZ6/06, and PZ19/06 and the parental strain P1. Data are presented as mean \pm standard deviation from six independent experiments. B, Concentration of secreted proteins in cultivation medium from Trichoderma DPM1-transformed strains. PZ1/06, PZ6/06, and PZ19/06 transformants and the control strain P1 were cultivated in minimal medium supplemented with lactose and an amount of proteins secreted to the medium was measured. Data are presented as mean \pm standard deviation from five independent experiments. C, Growth curves of PZ1/06, PZ6/06, and PZ19/06 transformants and the control strain. Strains were cultivated in the lactose-based medium. Data are presented as means \pm standard deviation from five independent experiments. the Pythium-overgrown area contained not-lysed mycelia, still, the real lysis zones seemed to be more extensive during confrontation with transformants compared with the control strain.

It is known that the presence of one fungal species (e.g., the pathogen Pythium) may induce in another species (e.g., the biocontrol agent Trichoderma) a complex chain of metabolic responses (Almeida et al. 2007; Benitez et al. 2004). Such responses may vary in different Trichoderma strains. To avoid this complication, we sought to study the antifungal properties of our transformants without subjecting them to the presence of the pathogen. To this end, we cultivated Trichoderma transformants and the control strain on plates covered with cellophane or dialysis membrane (cutoff size $=12 \mathrm{kDa}$ ). After the plates had been grown over, the cellophane or dialysis membrane with the Trichoderma spp. was removed and the plates were used for cultivation of the plant pathogens $P$. ultimum or $R$. solani. In this manner, we could study the influence of hydrolytic enzymes and metabolites or only metabolites secreted by Trichoderma spp. on the growth of the pathogens. A negative control comprised plates not subjected to Trichoderma spp. culturing. P. ultimum failed to grow on the pretreated plates regardless of the Trichoderma strain grown on the plates before, while the growth of $R$. solani was strongly inhibited by PZ1/06 and PZ6/06 and slightly by PZ19/06 and the control strain (Fig. 9). The effect was not dependent on the sort of membrane used in the experiments.

Because the confrontation experiments revealed enhanced antifungal properties of the transformed strains, we performed plant tests using the bean Phaseolus vulgaris L. Survival of bean seedlings in a soil infected by Pythium ultimum was reduced to $12.5 \%$ of control values in sterile soil (Fig. 10). Treatment of the seeds with any of the Trichoderma strains improved their germination substantially. Transformed Trichoderma strains increased the germination rate to $87.5 \%$ of the noninfected control and the control P1 strain to $63 \%$.

We also observed changes in the size of plants growing in soil infected by $P$. ultimum and protected by different Trichoderma strains. Infection by P. ultimum brought about an $85 \%$ inhibition of plant growth compared with noninfected plants. Plants protected by nontransformed $T$. atroviride $\mathrm{P} 1$ were smaller by $37 \%$ than the noninfected controls, while protection by the transformed strains was even better. In the presence of PZ1/06 and PZ6/06, the inhibition of seedling growth by $P$. $u l$ timum was strongly diminished to 15 and $10 \%$, respectively, while PZ19/06 not only completely nullified the inhibitory effect of the fungal pathogen but even caused the seedlings to grow better than the control without any fungus.

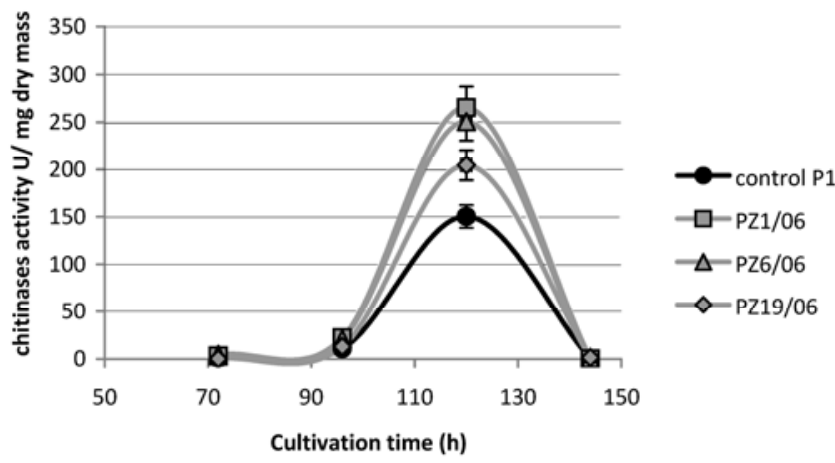

Fig. 6. $N$-acetyl- $\beta$-D-lucosaminidase activity in cultivation medium from DPM1-transformed Trichoderma spp. Concentration of $p$-nitrophenol cleaved out from the substrate ( $p$-nitrophenyl- $\beta$-D- $N$-acetylglucosaminide) was measured in cultivation medium from PZ1/06, PZ6/06, and PZ19/06 and the control P1 strain. Data are presented as mean \pm standard deviation from six separate cultures. 

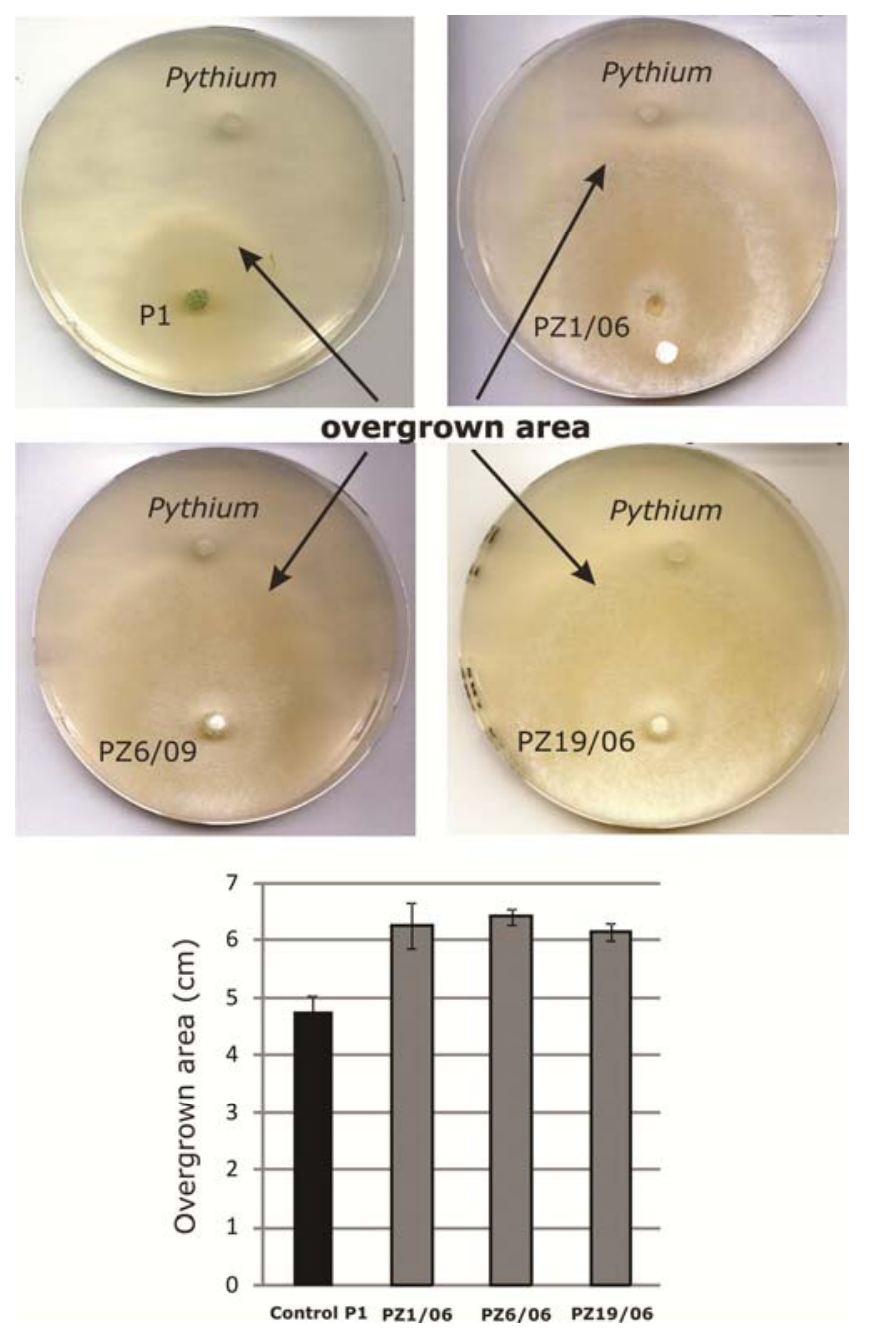

Fig. 7. Plate confrontation assay of Trichoderma atroviride against Pythium ultimum. Mycelial disks of PZ1/06, PZ6/06, and PZ19/06 transformants and the control strain and P. ultimum were placed at opposite sides of agar plates and incubated at $28^{\circ} \mathrm{C}$. Pictures were taken 3 days after inoculation. Arrows mark the overgrown zone between the two fungi. Overgrown zones were measured and results are presented as mean \pm standard deviation from six separate plates.

Survival of bean seedlings in a soil infected by $R$. solani was reduced to $38 \%$ of control values in sterile soil (Fig. 11). Transformed Trichoderma strains increased the germination rate to $75 \%$ of the control and the control P1 strain to $50 \%$. Infection by $R$. solani gave a $68 \%$ inhibition of plant growth compared with noninfected plants. Plants protected by the control strain P1 were 39\% smaller than the noninfected controls while, in the presence of PZ6/06 and PZ19/06, the plants growth was decreased to 29 and $31 \%$, respectively. On the other hand, plants protected by PZ1/06 strain were slightly smaller compared with the seedlings protected by the control P1 strain but the differences, although observed, were not statistically significant.

\section{DISCUSSION}

In this study, we sought to improve the antifungal and biocontrol properties of T. atroviride $\mathrm{P} 1$. We concentrated on the direct attack of the biocontrol agent on pathogenic fungi when the hydrolytic enzymes secreted by the biocontrol strain play a crucial role by attacking the cell wall of the pathogen, enabling subsequent penetration of its cells. To augment the production and secretion of these enzymes, we chose a strategy developed ear-

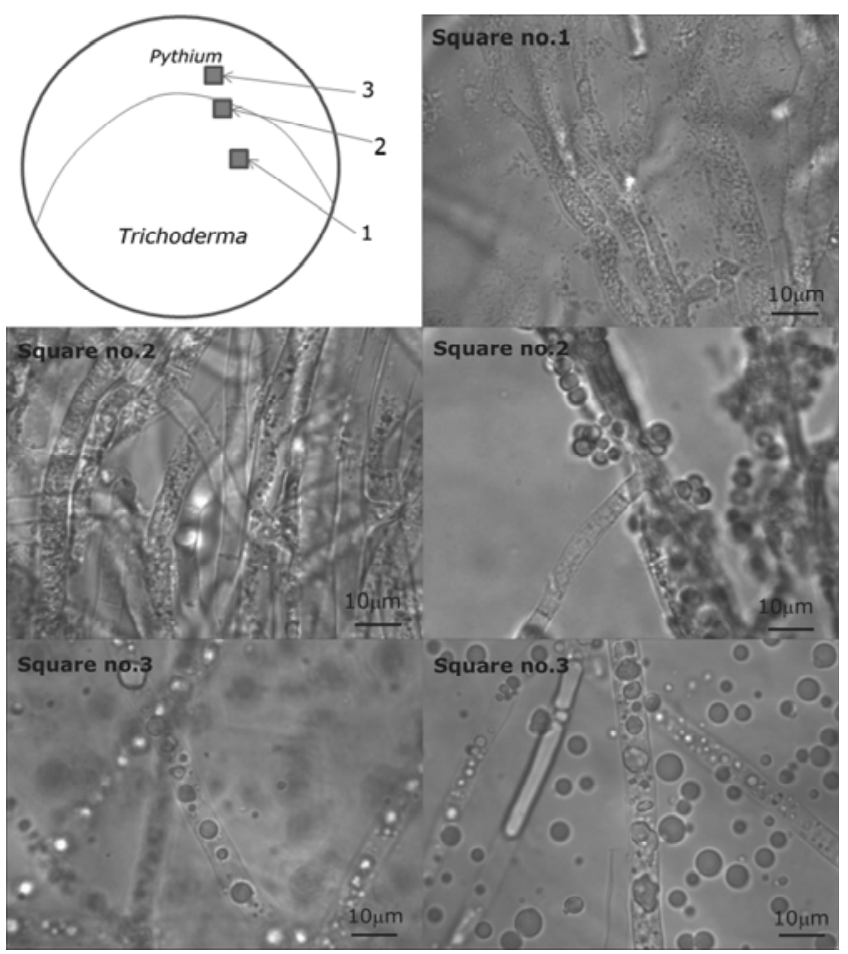

Fig. 8. Morphology of Pythium ultimum and Trichoderma atroviride hyphae during the confrontation assay. Microscopic analysis of three squares $(1,2$, and 3$)$ cut from the overgrown area. Squares number 1 and number 2 represent long and short contact of Pythium and Trichoderma spp., respectively. Square number 3 represents Pythium spp. not overgrown by T. atroviride. Magnification $\times 100$.

lier for T. reesei (Kruszewska et al. 1999; Perlińska-Lenart et al. 2006). We found then that production and secretion of hydrolytic enzymes could be elevated by more efficient modification of secretory proteins in the endoplasmic reticulum thanks to an increased activity of DPM synthase, a key enzyme of O-glycosylation. In this study, integration of additional copies of the $S$. cerevisiae DPM1 gene into the genome of T. atroviride $\mathrm{P} 1$ gave approximately twice higher DPM synthase activity, similar to that in the T. reesei DPM1 transformants, and also twice higher protein secretion, in contrast to the sevenfold higher secretion in T. reesei. The increase of the DPM synthase activity in T. reesei was not correlated with number of $D P M 1$ copies integrated into the genome, suggesting rather tight regulation of its expression and DPM synthase activity. In T. atroviride, we observed integration of two copies of the DPM1 gene in all of the transformants, apparently into the same site in the genome. This was expected because it had been shown previously by Herrera-Estrella and associates (1990) that integration of transforming DNA into the genome of biocontrol $T$. harzianum occurred in some preferred sites only. Despite the apparent genetic identity of all three transformants, PZ1/06 exhibited a DPM synthase activity $18 \%$ higher than that in the other two strains. The increased activity of DPM synthase allowed the transformants to grow better on media containing complex carbon sources, suggesting higher production and secretion of hydrolytic enzymes. Indeed, the cellulolytic activity measured in cultivation media of the transformants turned out to be more than double that of the control P1 strain. In line with that, the confrontation experiments with $P$. ultimum showed clearly enhanced antifungal properties of our transformants.

For an efficient cell wall lysis during an interaction between a mycoparasite and a pathogen, a combination of different hydrolytic activity is required. This caveat notwithstanding, a significantly higher biocontrol activity against $P$. ultimum was shown 


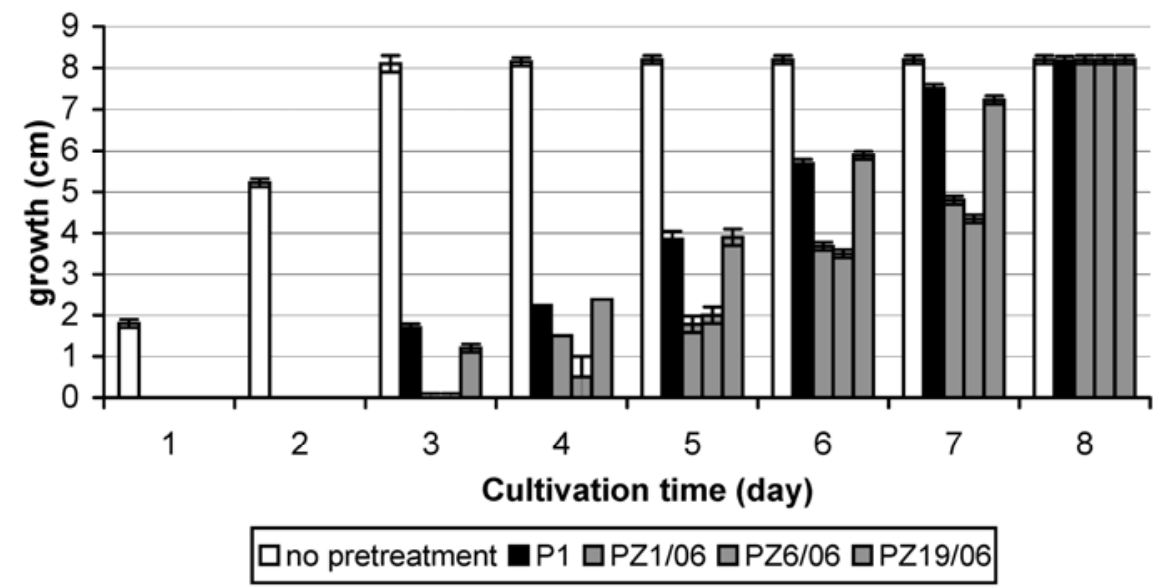

Fig. 9. Growth inhibition of Rhizoctonia solani cultivated on plates pretreated with Trichoderma atroviride strains. PZ1/06, PZ6/06, and PZ19/06 and the parental strain were cultivated on minimal medium containing plates covered with cellophane. $R$. solani was inoculated on the pretreated plates. As a control, $R$. solani was cultivated on a non-pretreated plates. Data are presented as mean \pm standard deviation from six separate experiments.
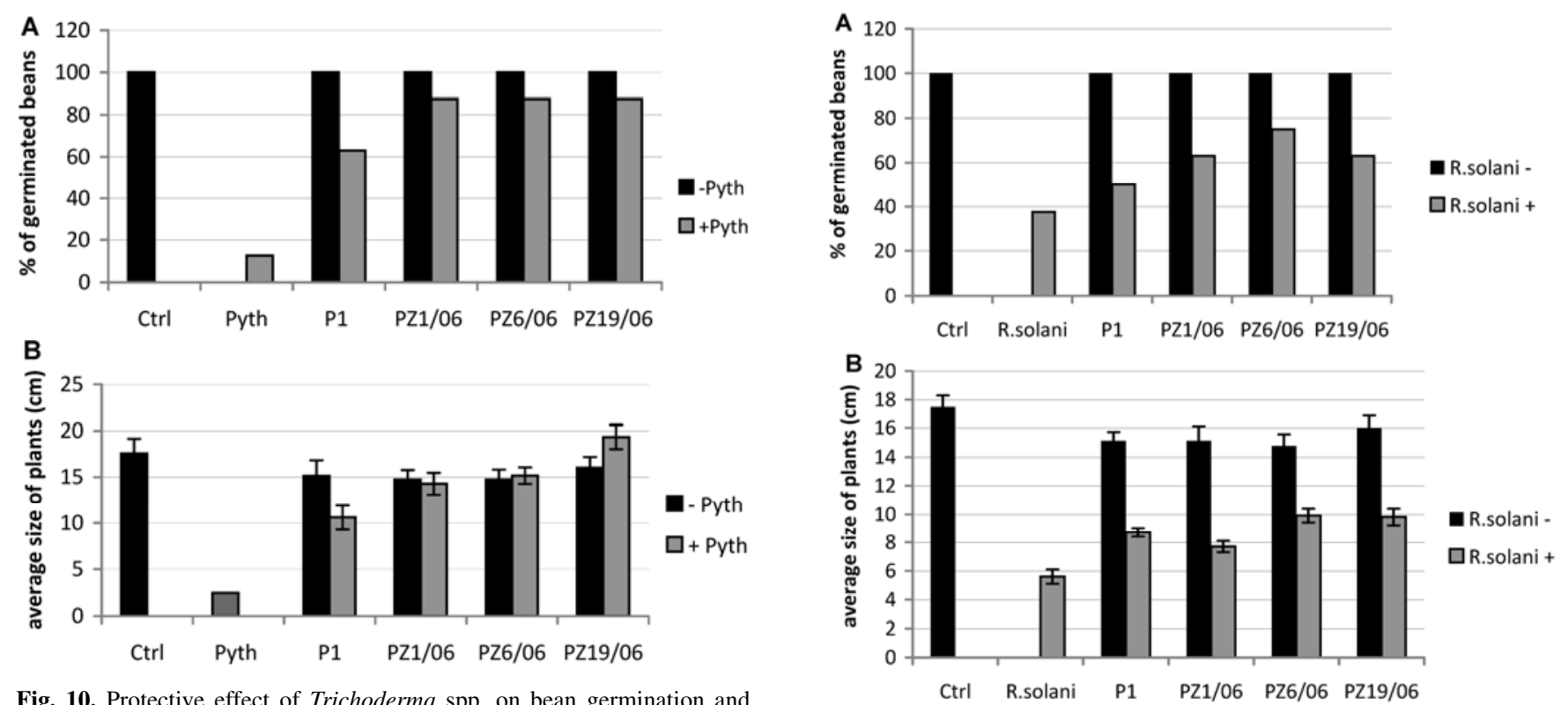

Fig. 10. Protective effect of Trichoderma spp. on bean germination and seedling growth in Pythium ultimum-infected soil. Efficiency of germination presented as $\mathbf{A}$, percentage of seed sown and $\mathbf{B}$, average size of seedlings measured as seedling height. Both were analyzed after 10 days. Seeds were sown in sterile (black bars) or P. ultimum-infected (gray bars) soil in the absence or presence of Trichoderma strains as indicated. $\mathrm{Ctrl}=$ seed grown in sterile soil without any fungus. Each bar represents mean \pm standard deviation from 16 independent experiments.

for T. longibrachiatum transformed with a $\beta$-1,4-endoglucanaseencoding gene (Migheli et al. 1998), although those authors considered a likely synergistic effect of other hydrolytic enzymes.

Also, a protein extract from cultivation media of $T$. virens overexpressing $\beta$-1-6 glucanase inhibited Pythium spp. growth more effectively than the extract from a nontransformed strain, demonstrating an involvement of this enzyme in the mycoparasitism against Pythium (Djonovic et al. 2006). In this report, the growth of $P$. ultimum was completely prevented by products secreted to the medium by $T$. atroviride P1, both the DPM1-transformed and nontransformed one. $R$. solani was less sensitive and allowed demonstration of a stronger antifungal activity of two of our DPM1 transformants compared with the nontransformed control and, unexpectedly, the third transformant.

These differences in the sensitivity of the two pathogens to the metabolites secreted by Trichoderma spp. are likely to be due to their different cell wall composition, especially the pau-

Fig. 11. Protective effect of Trichoderma spp. on bean germination and seedling growth in Rhizoctonia solani-infected soil. Efficiency of germination presented as $\mathbf{A}$, percentage of seed sown and $\mathbf{B}$, average size of seedlings measured as seedling height. Both were analyzed after 10 days. Seeds were sown in sterile (black bars) or $R$. solani-infected (gray bars) soil in the absence or presence of Trichoderma strains as indicated. Ctrl = seed grown in sterile soil without any fungus. Each bar represents mean \pm standard deviation from 16 independent experiments.

city of chitin in the cell wall of Pythium spp. (Latijnhouwers et al. 2003). Although we focus here on hydrolytic enzymes, one should not forget that Trichoderma spp. also secrete a wide range of secondary metabolites such as potential antibiotics, terpenes, polypeptides, and pyrones, all of mycotoxic activity (Schuster and Schmoll 2010). More efficiently inhibited growth of $R$. solani on plates pretreated by Trichoderma transformants cultivated on media covered with dialysis membrane permeable for small molecules suggests that secondary metabolites could be secreted in higher amounts by our transformants. These results could point at the indirect influence of the DPMI gene overexpression or elevated activity of DPM synthase on the metabolic pathways not directly connected with protein glycosylation.

Our promising results obtained with pure fungal culture were further corroborated by simple biocontrol experiments. 
Trichoderma spp. indeed protected bean seedlings against $P$. ultimum, and DPM1 transformants were substantially better in this respect than the nontransformed control. Protection of plants against $R$. solani was also observed, although the effect was not as pronounced.

To conclude, a simple manipulation of the O-glycosylation pathway increased the secretion and activity of hydrolytic enzymes by Trichoderma spp., thus boosting their antifungal and biocontrol activity and opening new perspectives for biotechnological applications.

\section{MATERIALS AND METHODS}

T. atroviride strain P1 ("Trichoderma harzianum", American Type Culture Collection number 74058) was used as the recipient strain for transformation. Escherichia coli strain JM 109 was used for plasmid propagation (Yanish-Perron et al. 1985). T. atroviride was cultivated at $28^{\circ} \mathrm{C}$ on a rotary shaker (250 rpm) in 2-liter shake flasks containing 1 liter of minimal medium (MM): $1 \mathrm{~g}$ of $\mathrm{MgSO}_{4} \times 7 \mathrm{H}_{2} \mathrm{O}, 6 \mathrm{~g}$ of $\left(\mathrm{NH}_{4}\right)_{2} \mathrm{SO}_{4}, 10$ $\mathrm{g}$ of $\mathrm{KH}_{2} \mathrm{PO}_{4}, 3 \mathrm{~g}$ of sodium citrate $\times 2 \mathrm{H}_{2} \mathrm{O}$, and trace elements $\left(25 \mathrm{mg}\right.$ of $\mathrm{FeSO}_{4} \times 7 \mathrm{H}_{2} \mathrm{O}, 2.7 \mathrm{mg}$ of $\mathrm{MnCl}_{2} \times 4 \mathrm{H}_{2} \mathrm{O}$, $6.2 \mathrm{mg}$ of $\mathrm{ZnSO}_{4} \times 7 \mathrm{H}_{2} \mathrm{O}$, and $14 \mathrm{mg}$ of $\left.\mathrm{CaCl}_{2} \times 2 \mathrm{H}_{2} \mathrm{O}\right)$ per liter and $1 \%(\mathrm{wt} / \mathrm{vol})$ lactose or glucose as a carbon source. The flasks were inoculated with $42 \times 10^{6}$ conidia per one medium.

Fungal dry weight was quantified by filtering culture samples through G1 sintered glass funnels, washing the biomass with water, and drying to a constant weight at $110^{\circ} \mathrm{C}$.

To measure utilization of different carbon sources by DPM1 transformants, 5-mm discs of mycelia were placed on agar plates containing MM supplemented with xylan, cellulose, or carboxymethylcellulose as a carbon source (10 g/liter) and incubated at $28^{\circ} \mathrm{C}$ for 3 days. Every day, the area of growth was measured. Six replicates were prepared for each experiment and for each transformants.

Pythium ultimum strain 8 was grown on potato-dextrose agar (PDA) (Difco-BD, Becton Dickinson and Company, Sparks, MD, U.S.A.).

\section{Expression of the $S$. cerevisiae DPM1 gene in $T$. atroviride.}

T. atroviride P1 was cotransformed with the yeast DPM1 gene fused under the A. nidulans gpdA gene promoter (glyceraldehyde- 3 phosphate dehydrogenase) and $\operatorname{trp} C$ (indole-3glycerol phosphate synthase) terminator, using pAN52-1NotI plasmid (National Center for Biotechnology Information accession number Z32697). The complete coding sequence of the $S$. cerevisiae DPM1 gene was amplified by polymerase chain reactin (PCR), using the Expand High Fidelity PCR System (Boehringer Mannheim, Vienna). Primers DPM1s (5' AGC ATC GAA TAC TCT GTT ATC GTT 3') and DPM1r (5' TTA AAA GAC CAA ATG GTA TAG CTG 3') were used for gene amplification. The pAN521N plasmid was cut between the promoter and the terminator with BamHI, the sticky ends were blunted with mung bean nuclease (Promega Corp., Madison, WI, U.S.A.), and the PCR product was ligated with the plasmid (Kruszewska et al. 1999). The pRMLex_30 plasmid with $E$. coli hygromycin B phosphotransferase gene $(h p h)$ fused between promoter and terminator elements of the homologous Trichoderma pkil (coding for pyruvate kinase) and $c b h 2$ (encoding cellobiohydrolase II) genes was used as a partner in cotransformation. Transformants were selected for hygromycine B resistance on plates containing $1.2 \mathrm{M}$ sorbitol and hygromycin B (Sigma-Aldrich, St. Louis) at 200 $\mu \mathrm{g} / \mathrm{ml}$.

The transformants were then cultivated in liquid MM for preparation of DNA.
Molecular biology methods.

Chromosomal DNA was isolated from T. atroviride using the Promega Wizard Genomic DNA Purification kit. Total RNA was isolated using the single-step method described by Chomczynski and Sacchi (1987). Other molecular biology procedures were performed according to standard protocols (Sambrook et al. 1989).

\section{Membrane fraction preparation and DPM synthase activity.}

Trichoderma spp. were harvested and resuspended in $25 \mathrm{ml}$ of $150 \mathrm{mM}$ Tris- $\mathrm{HCl}$ buffer, $\mathrm{pH} 7.4$, containing $15 \mathrm{mM} \mathrm{MgCl}_{2}$ and $9 \mathrm{mM}$ 2-mercaptoethanol. The cells were homogenized and the homogenate was centrifuged at $4,000 \times g$ for $10 \mathrm{~min}$. The supernatant was centrifuged for $1 \mathrm{~h}$ at $50,000 \times g$. DPM synthase activity was measured in the pelleted membrane fraction by incubating it with GDP $\left[{ }^{14} \mathrm{C}\right]$ Mannose (sp.act. 288 $\mathrm{Ci} / \mathrm{mol}$ ) (Amersham, Buckinghamshire, U.K.) and $5 \mathrm{ng}$ of dolichyl phosphate (Dol-P) according to Kruszewska and associates (1989).

\section{Cellulase activity.}

The activity of cellulases was measured in the cultivation medium by incubation of $0.5 \mathrm{ml}$ of carboxymethylcellulose $(10 \mathrm{~g} /$ liter $)$ in $50 \mathrm{mM}$ sodium citrate buffer $\left(\mathrm{pH} \mathrm{5.0)}\right.$ at $50^{\circ} \mathrm{C}$ for $10 \mathrm{~min}$ with $0.2 \mathrm{ml}$ of culture filtrate. The reaction was stopped by boiling for $5 \mathrm{~min}$. The amount of reducing sugars formed was determined by the method of Bernfeld (1955) and estimated using a standard curve prepared with glucose.

\section{$N$-acetyl- $\beta$-D-glucosaminidase assay.}

$N$-acetyl- $\beta$-D-glucosaminidase activity was measured in the cultivation medium after $120 \mathrm{~h}$ of cultivation, as described by Brunner and associates (2003), by monitoring the release of $p$ nitrophenol from $p$-nitrophenyl- $\beta$-D- $N$-acetylglucosaminide ( $p$ NP-GlcNAc) (Carbosynth Ltd., Compton-Berkshire, U.K.) at $405 \mathrm{~nm}$. The enzyme solution $(50 \mu \mathrm{l})$ was added to $800 \mu \mathrm{l}$ of $p$ NPGlcNAc $(1 \mathrm{mg} / \mathrm{ml})$ dissolved in $0.09 \mathrm{M}$ citrate buffer $(\mathrm{pH}$ 4.8). After incubation for $2 \mathrm{~h}$ at $37^{\circ} \mathrm{C}$, the reaction was terminated by the addition of $2 \mathrm{ml}$ of $0.4 \mathrm{M}$ sodium carbonate. One unit of activity was defined as the amount of enzyme that liberated $1 \mu \mathrm{g}$ of $p \mathrm{NP}$ from the substrate per $2 \mathrm{~h}$.

\section{Quantification of saccharides bound to secreted proteins.}

The saccharides bound to the proteins isolated from the $T$. atroviride culture filtrates were assayed by the phenol-sulfuric acid procedure (Dubois et al. 1956). Secreted proteins were precipitated with two volumes of $96 \%$ ethanol, washed twice with $70 \%$ ethanol, and dissolved in distilled water (Ma et al. 1996).

The concentration of carbohydrates was measured in the pellet. The calibration curve was prepared with D-mannose.

\section{Plate confrontation assay and microscopic analysis.}

Mycelial disks $(5 \mathrm{~mm})$ of $T$. atroviride DPM1 transformants and $P$. ultimum were placed at opposite sides (4 cm apart) of agar plates with MM supplemented with $1 \%$ glucose. The plates were incubated at $28^{\circ} \mathrm{C}$ and photographs were taken after 3 days of incubation. Six replicates were prepared for each experiment and for each transformant.

From three different places of the overgrown area, thin agar discs were cut out and analyzed under a Delta Optical Evolution 100 microscope.

\section{Fungal growth inhibition.}

MM-containing plates were covered with sterile cellophane sheets or dialysis membrane (cutoff size $=12 \mathrm{kDa}$ ) (Sigma-Al- 
drich) and Trichoderma strains were allowed to grow over the plate; then, the cellophane was removed together with the Trichoderma cells and a 5-mm mycelial disk of $R$. solani or $P$. ultimum was placed in the center of the plate. Plates were incubated at $28^{\circ} \mathrm{C}$ for 8 days. Every day, the area of growth was measured. Three replicates were prepared for each experiment and for each transformant. As a control, the pathogenic fungi were cultivated on MM-containing plates not pretreated with Trichoderma spp.

\section{Biocontrol assay.}

Bean seeds (Phaseolus vulgaris L. (var. nanus L.)) were coated with $5 \times 10^{8}$ spores per $10 \mathrm{~g}$ of seed. Pathogen-infected soil was prepared by adding $2.2 \mathrm{~g}$ of fungal biomass of $P y$ thium ultimum or $R$. solani to 1 liter of sterile soil. Bean seeds were allowed to germinate in the moist soil for 10 days and the number and height of the seedlings was investigated.

\section{ACKNOWLEDGMENTS}

This work was partially supported by the State Committee for Scientific Research, Poland, grant number 1307/P01/2006/31; Operational Programme-Innovative Economy, Poland, grant number UDA-POIG.01.03.0114-038/09 to J. S. Kruszewska; and a Maria Curie Scholarship to P. Zembek in R. L. Mach's Laboratory and grant of FWF Austrian science fund (P21584) to B. Reithner.

\section{LITERATURE CITED}

Almeida, F. B., Cerqueira, F. M., Silva, R. N., Ulhoa, C. J., and Lima A. L. 2007. Mycoparasitism studies of Trichoderma harzianum strains against Rhizoctonia solani: Evaluation of coiling and hydrolytic enzyme production. Biotechnol. Lett. 29:1189-1193.

Baek, J., Howell, C. R., and Kenerley, C. M. 1999. The role of an extracellular chitinase from Trichoderma virens Gv29-8 in the biocontrol of Rhizoctonia solani. Curr. Genet. 35:41-50.

Benitez, T., Rincon, A. M., Limon, M. C., and Codon, A. C. 2004. Biocontrol mechanisms of Trichoderma strains. Int. Microbiol. 7:249-260.

Bernfeld, P. 1955. Amylases $\alpha$ and $\beta$. Methods Enzymol. 1:149-158.

Brunner, K., Peterbauer, C. K., Mach, R. L., Lorito, M., Zelinger, S., and Kubicek, C. P. 2003. The Nag1 N-acetylglucosaminidase of Trichoderma atroviride is essential for chitinase induction by chitin and of major relevance to biocontrol. Curr. Genet. 43:289-295.

Carsolio, C., Benhamou, N., Haran, S., Cortes, C., Gutierrez, A., Chet, I., and Herrera-Estrella, A. 1999. Role of the Trichoderma harzianum endochitinase gene ech42, in mycoparasitism. Appl. Environ. Microbiol. 65:929-935

Chet, I., Benhamou, N., and Haran, S. 1998. Mycoparasitism and lytic enzymes. Pages 153-172 in: Trichoderma and Glocladium, vol. 2. E. G. Harman and C. P. Kubicek, eds. Taylor and Francis Ltd., London.

Chomczynski, P., and Sacchi, N. 1987. Single-step method of RNA isolation by acid guanidinum thiocyanate-phenol-chloroform extraction. Anal. Biochem. 162:156-159.

Djonovic, S., Pozo, M. J., and Kenerley, C. M. 2006. Tvbgn3, a $\beta-1,6-$ glucanase from the biocontrol fungus Trichoderma virens, is involved in mycoparasitism and control of Pythium ultimum. Appl. Environ. Microbiol.72:7661-7670.

Dubois, M., Gilles, K. A., Hamilton, J. K., Robers, P. A., and Smith, F. 1956. Colorimetric method for determination of sugar and related substrates. Anal. Biochem. 28:350-356.

Flores, A., Chet, I., and Herrera Estrella, A. 1997. Improved biocontrol activity of Trichoderma harzianum by over-expression of the proteinaseencoding gene prb1. Curr. Genet. 31:30-37.

Harman, G. E. 2006. Overview of mechanisms and uses of Trichoderma spp. Phytopathology 96:190-194.

Herrera-Estrella, A., Goldman, G. H., and Van Montagu, M. 1990. Highefficiency transformation system for the biocontrol agents, Trichoderma spp. Mol. Microbiol. 4:839-843.

Hjeljord, L., and Tronsmo, A. 1998.Trichoderma and Gliocladium in biological control: An overview. Pages 131-151 in: Trichoderma and Gliocladium, vol. 2. E. G. Harman and C. P. Kubicek, eds. Taylor and Francis Ltd., London.

Kruszewska, J., Messner, R., Kubicek, C. P., and Palamarczyk, G. 1989. O-glycosylation of proteins by membrane fraction of Trichoderma reesei QM9414. J. Gen. Microbiol. 135:301-307.

Kruszewska, J., Palamarczyk, G., and Kubicek, C. P. 1990. Stimulation of exoprotein secretion by choline and Tween 80 in Trichoderma reesei QM 9414 correlates with increased activity of dolichol phosphate mannose synthase. J. Gen. Microbiol. 136:1293-1298.

Kruszewska, J., Butterweck, A. H., Kurzątkowski, W., Migdalski, A., Kubicek, C. P., and Palamarczyk, G. 1999. Overexpression of the Saccharomyces cerevisiae mannosylphosphodolichol synthase-encoding gene in Trichoderma reesei results in an increased level of protein secretion and abnormal cell ultrastructure. Appl. Environ. Microbiol. 65:2382-2387.

Kubicek, C. P., Panda, T., Schreferl-Kunar, G., Messner, R., and Gruber, F. 1987. O-linked-but not N-linked-glycosylation is necessary for secretion of endoglucanase I and II by Trichoderma reesei. Can. J. Microbiol. 33:698-703.

Kulling, C., Mach, R. L., Lorito, M., and Kubicek, C. P., 2000. Enzyme diffusion from Trichoderma atroviride (=T. harzanum P1) to Rhizoctonia solani is a prerequisite for triggering of Trichoderma ech 42 gene expression before mycoparasitic contact. Appl. Environ. Microbiol. 66:2232-2234.

Latijnhouwers, M., de Wit, P. J. G. M., and Govers, F., 2003. Oomycetea and fungi: Similar weaponry to attack plants. Trends Microbiol. 11:462-469.

Ma, J., Stoter, G., Verweij, J., and Shellens, J. H., 1996. Comparison of ethanol plasma-protein precipitation with plasma ultrafiltration and trichloroacetic acid protein precipitation for the measurement of unbound platinum concentrations. Cancer Chemother. Pharmacol. 38:391-394.

Migheli, Q., González-Candelas, L., Dealessi, L., Camponogara, A., and Ramón-Vidal, D. 1998. Transformants of Trichoderma longibrachiatum overexpressing the $\beta-1,4$-endoglucanase gene egll show enhanced biocontrol of Pythium ultimum on cucumber. Phytopathology 88:673-677.

Montero, M., Sanz, L., Rey, M., Llobell, A., and Monte, E., 2007. Cloning and characterization of bgn 16.3 , coding for a $\beta$-1,6-glucanase expressed during Trichoderma harzianum mycoparasitism. J. Appl. Microbiol. 103:1291-1300.

Perlińska-Lenart, U., Orłowski, J., Laudy, A. E., Zdebska, E., Palamarczyk, G., and Kruszewska, J. S. 2006. Glycoprotein hypersecretion alters the cell wall in Trichoderma reesei strains expressing the Saccharomyces cerevisiae dolichylphosphate mannose synthase gene. Appl. Environ. Microbiol. 72:7778-7784.

Sambrook, J., Fritsch, E. F., and Maniatis, T. 1989. Pages 7.37-7.52 in: Molecular Cloning: A Laboratory Manual, vol. 1, 2nd ed. Cold Spring Harbor Laboratory Press, Cold Spring Harbor, NY, U.S.A.

Scherm, B., Schmoll, M., Balmas, V., Kubicek, C. P., and Migheli, Q. 2009. Identification of potential marker genes for Trichoderma harzianum strains with high antagonistic potential against Rhizoctonia solani by a rapid subtraction hybridization approach. Curr. Genet. 55:8191.

Schuster, A., and Schmoll, M. 2010. Biology and biotechnology of Trichoderma. Appl. Microbiol. Biotechnol. 87:787-799.

Steyaert, J. M. 2004. Co-expression of two genes, a chitinase (chit42) and proteinase (prn1), implicated in mycoparasitism by Trichoderma hamatum. Mycologia 96:1245-1252.

Suarez, B., Sanz, L., Chamorro, I., Rey, M., Gonzalez, F. J., Llobell, A., and Monte, E. 2005. Proteomic analysis of secreted proteins from Trichoderma harzianum Identification of a fungal cell wall induced aspartic protease. Fungal Genet. Biol. 42:924-934.

Viterbo, A., Ramot, O., Chemin, L., and Chet, I. 2002. Significance of lytic enzymes from Trichoderma spp. in the biocontrol of fungal plant pathogens. Antonie Leeuwenhoek 81:549-556.

Woo, S. L., Scala, F., Ruocco, M., and Lorito, M. 2006. The molecular biology of the interactions between Trichoderma spp., phytopathogenic fungi, and plants. Phytopathology 96:181-185.

Yan, L., and Qian, Y. 2009. Cloning and heterologous expression of SS10, a subtilisin-like protease displaying antifungal activity from Trichoderma harzianum. FEMS (Fed. Eur. Microbiol. Soc.) Microbiol. Lett. 290:54-61.

Yanish-Perron, C., Vieira, J., and Messing, J. 1985. Improved M13 phage cloning vectors and host strains: Nucleotide sequences of the M13mp18 and pUC 19 vectors. Gene 33:103-119.

Zakrzewska, A., Palamarczyk, G., Krotkiewski, H., Zdebska, E., Saloheimo, M., Penttilä, M., and Kruszewska, J. S. 2003. Overexpression of the gene encoding GTP-mannose-1-phosphate guanyltransferase, mpgl, increases cellular GDP-mannose levels and protein mannosylation in Trichoderma reesei. Appl. Environ. Microbiol. 69:4383-4389.

Zeilinger, S., Galhaup, C., Payer, K., Woo, S. L., Mach, R. L., Fekete, C., Lorito, M., and Kubicek, C. P. 1999. Chitinase gene expression during mycoparasitic interaction of Trichoderma harzianum with its host. Fungal Genet. Biol. 26:131-140. 